\title{
AN OVERVIEW OF THE TURKISH HEALTH SECTOR ${ }^{(1)}$
}

\section{TÜRKIYYE SAĞLIK SEKTÖRÜNE GENEL BAKIŞ}

Ali Serdar YÜCEL ${ }^{1}$, Perihan ABAY ${ }^{2}$, Ayhan AYTAÇ, Ümran SEVIL ${ }^{4}$, Ayça GÜRKAN, Çetin YAMAN', Murat KORKMAZ7, Yasemin KÜÇÜKÖZKAN ${ }^{8}$

${ }^{1}$ Firat University, Faculty of Sports Sciences, Elazı̆ / Turkey

${ }^{2}$ Kanuni Sultan Süleyman Training and Research Hospital, Istanbul / Turkey

${ }^{3}$ Trakya University, Faculty of Economics and Administrative Sciences, Edirne / Turkey

${ }^{4-5}$ Ege University, Faculty of Nursing, Izmir / Turkey

${ }^{6}$ Sakarya Applied Sciences University, Faculty of Sports Sciences, Sakarya / Turkey

${ }^{7}$ Güven Plus Grup Counselling Inc. Istanbul/ Turkey

ORCID ID: 0000-0003-3416-4663', 0000-0002-7407-9175², 0000-0002-5599-2399³, 0000-0002-8973-30024, 0000-0001-6962-30955, 0000-0002-0888-2154,

0000-0001-7925-5142 , 0000-0001-7042-5432

Öz: Türkiye Sağlık harcamaları 2009 yılından beri istikrarlı bir şekilde büyümektedir. Yıllık ortalama büyüme oranı \%10'un üzerindedir. Sektör büyüklüğ̈ 2017 yılında 412 milyar TL'ye ulaşmıştır. Bu çalışmanın amacı finansman kaynağı, finansman hedefi ve sağlık hizmetleri talebine göre sağlık harcamalarının incelenmesidir. Çalışmada kullanılan veriler TUiK web sitesinden ilgili dönem için elde edilen verilerdir. Bu çalışma TUIK tarafindan düzenli olarak yayınlanan 2009 ve 2017 yıllarına ait sağılk harcamaları verilerinin istatistiksel olarak düzenlenerek analiz edilmesi sonrasında hazırlanmıştır. Analiz kapsamında Regresyon, ANOVA ve CAGR ve temel istatistiksel yöntemler kullanılmıștır. Analizler SPSS ve Eviews programı kullanılarak gerçekleştirilmiş̦tir. Calışmada elde edilen bulgulara göre 2018 yilı sonunda kamu ve özel hizmet sağlayıcılarının sağlık harcamalarının toplamı 467.310 Milyon TL olması beklenmektedir. Özel hizmet sunucularına yapılan harcamaların 2009 yilından beri genel hizmet sunucu sektörüyle paralel bir büyüme sergilediği, 2017 yllında özel hizmet sunucularının toplam sağlık harcamalarındaki payının \%22 oranında olduğu görülmektedir. Ayrıca 2018 yılı sonunda özel hizmet sağlayıcılarının sağlık harcamaları toplamının 102.098 Milyon TL olması beklenmektedir. Çalışma sonunda sağılı harcamalarının GSYiH içindeki payının diğer OECD ülkelerinden daha düşük olduğu ve bu durumun yüksek büyüme potansiyeline işaret ettiği belirlenmiștir. Türkiye'deki yaşlı ve yüksek risk taşıyan yaş gruplarının, sağlık harcamalarında artışı gösterecek şekilde yaş segmentlerinden daha hızlı büyümekte olduğu ve yıllara göre bakıldığında yaş gruplarının büyüklüğünün istatistiksel olarak farklılaşmakta olduğu sonucuna ulaşılmıștır.

Anahtar Kelimeler: Sağılk, Yönetim, Sektör, Piyasa, Ekonomi
Abstract: Turkey's health spending has been growing steadily since 2009. Annual average growth rate is over $10 \%$. The sector size reached 412 billion TL in 2017. The aim of this study is to examine health expenditures according to the source of financing, financing target and demand for health services. The data used in the study are obtained from the TurkStat website for the relevant period. This study was prepared after statistical editing and analysis of health expenditures data for 2009 and 2017 published by TurkStat. Regression, ANOVA and CAGR and basic statistical methods were used in the analysis. The analyzes were performed by using SPSS and Eviews program. According to the findings of the study, the total health expenditures of public and private service providers are expected to be 467.310 Million TL by the end of 2018. It has been observed that expenditures on private service providers have been growing parallel to the general service provider sector since 2009, and the share of private service providers in total health expenditures is $22 \%$ in 2017. In addition, the total health expenditures of private service providers are expected to be 102,098 Million TL by the end of 2018. At the end of the study, it was determined that the share of health expenditures in GDP was lower than other $\mathrm{OECD}$ countries and this indicates high growth potential. It has been concluded that the age groups of the elderly and high risk in Turkey are growing faster than the age segments to show growth in health care spending and the size of the age groups have statistically differed over the years.

Key Words: Health, Management, Sector, Market, Economy

Doi: 10.17363/SSTB.2019.33.2

(1) Sorumlu Yazar, Corresponding Author: Ali Serdar YÜCEL “Doç. Dr., Assoc. Prof”, Firat University, Faculty of Sports Sciences, Elazı̆ / Turkey, alsetu_23@hotmail.com, Geliş Tarihi / Received: 16.08.2019, Kabul Tarihi / Accepted: 19.11.2019, Makalenin Türü: Type of Article: (Araştırma-Uygulama; Research-Application) Çıkar Çatışması, Yok - Conflict of Interest, No, Etik Kurul Raporu veya Kurum İzin Bilgisi- Ethical Board Report or Institutiunal Approval, Yok/No 
International Refereed Academic Journal of Sports, Health and Medical Sciences

October - November - December Issue: 33 Fall Winter Semester Year: 2019

Uluslararası Hakemli Akademik Spor Sağlık ve Tıp Bilimleri Dergisi

Ekim - Kasım - Aralık Sayı: 33 Güz Kış Dönemi Yıl: 2019 ID:469 K:03

ISSN Print: 2146-8508 Online 2147-1711

(ISO 18001-OH-0090-13001706 / ISO 14001-EM-0090-13001706 / ISO 9001-QM-0090-13001706 / ISO 10002-CM-0090-13001706) (TRADEMARK)

(2015/04315- 2015-GE-18972)

\section{INTRODUCTION}

Undoubtedly, the survival and development of human beings depends on the growth of healthy generations and their economic wellbeing. Health expenditures which cover all expenditures made to protect, improve and maintain the health of people increase the level of health of the individual and society, and affect economic growth with the contributions made to human capital (Tıraş and Ağır, 2018: 26).

Health is a public service and an obligation. Therefore, practices and sanctions for the health sector within the public service concept bring new differences to our lives day by day. This situation which arises due to the developing technology also gives rise to differences in the development, renewal of inter-institutional and international strategies, and the differences between competitive and preferable reasons. When we look at personal health expenditures, we see that there are multi-faceted expenditure items in terms of care and change besides compulsory health expenditures. This situation varies from person to person, but also varies in the institutional sense.

Especially in recent years, developments in personal care and health tourism are closely monitored and observed. When we look at the results, we can say that it has become a sector.
Many world countries want to benefit from this sector on their behalf and do what is necessary in terms of competitiveness and preferability. There are different studies on this subject. These are made up of different scientific and public studies. When we want to look at health sector and economy in terms of literature, we see that it is examined in terms of many different variables.

Health services are important for economic growth and development, for increasing the productivity of the labor force, for the peace and welfare of the society (Tıraş and A $\breve{g} ı$, 2017: 196), and health is the indispensable part and source of human life. This is a fundamental need, and it can never be postponed and put into a second plan. The services and products to be provided for a healthy life must be accepted by the buyer and create benefit (Demir, 2011: 1-115).

Health expenditures, which is one of the basic indicators of development, are extremely important for the national economies. Regardless of the level of development of the country, various health problems are faced and more expenditure is spent on health expenditures. Health expenditures are defined as the sum of both public and private expenditures for all health related goods and services. The increase in health expenditures positively affects the life expectancy and quality of individuals. Basically, it can be said that eco- 
International Refereed Academic Journal of Sports, Health and Medical Sciences October - November - December Issue: 33 Fall Winter Semester Year: 2019

Uluslararası Hakemli Akademik Spor Sağlık ve Tıp Bilimleri Dergisi

Ekim - Kasım - Aralık Sayı: 33 Güz Kış Dönemi Yıl: 2019 ID:469 K:03

ISSN Print: 2146-8508 Online 2147-1711

(ISO 18001-OH-0090-13001706 / ISO 14001-EM-0090-13001706 / ISO 9001-QM-0090-13001706 / ISO 10002-CM-0090-13001706) (TRADEMARK)

(2015/04315- 2015-GE-18972)

nomic, technological, social and cultural factors increase health expenditures (Şahin and Temelli, 2019).

Expenditures for all protection, promotion, care, nutrition and emergency programs that adopt the purpose of health promotion or protection are considered as "Health Expenditure" (Yalçın and Çakmak, 2016: 716). Health expenditures are provided from public and private sector sources. Public sector health expenditures include central government and local government and social security fund expenditures while private sector expenditures are mostly from household pockets, payments made by firms for personnel, private health insurances and non-profit organizations serving households (Yurdadoğ, 2007). While health expenditures vary according to countries' level of development, the majority of Turkey's total health expenditure has been realized by the public (Öztürk and Uçan, 2017: 139-147).

Health economics is an important issue for many countries in the world, including Turkey. Health expenditures and health investments are an important factor for individual and public expenditure and saving outside the national economy. Public health expenditures cover a significant point in the general country budget and constitute a significant expenditure item. Comparing the health expenditures of Turkey to different world countries, we can say that this is difficult and troublesome.

Comparing, analyzing and examining data on health expenditure and health management of developed and developing world countries is important for the relevant country. Data analysis is very important for the evaluation and analysis of health expenditures in the sense of carrying out future plans and projects and especially for new investments to be made (Çelik, 2011: 62-81).

With the positive effect of health expenditures on the improvement of health services, the growth experienced in the economy will facilitate the shifting of the increased resources towards human capital investments and a higher growth will be achieved. Achieving economic growth increases the share of health expenditures and makes it possible to make more health expenditures (Akıncı and Tuncer, 2016: 58-59). Many research results show that economic growth improves health and improvements in health have a significant impact on economic efficiency and growth (Atun and Fitzpatrick, 2005: 6).

Three different methods of analysis and financing are used for health expenditures in Turkey. These are;

1. Public Financing Model,

2. Special Financing Model,

3. Mixed Financing Model. 


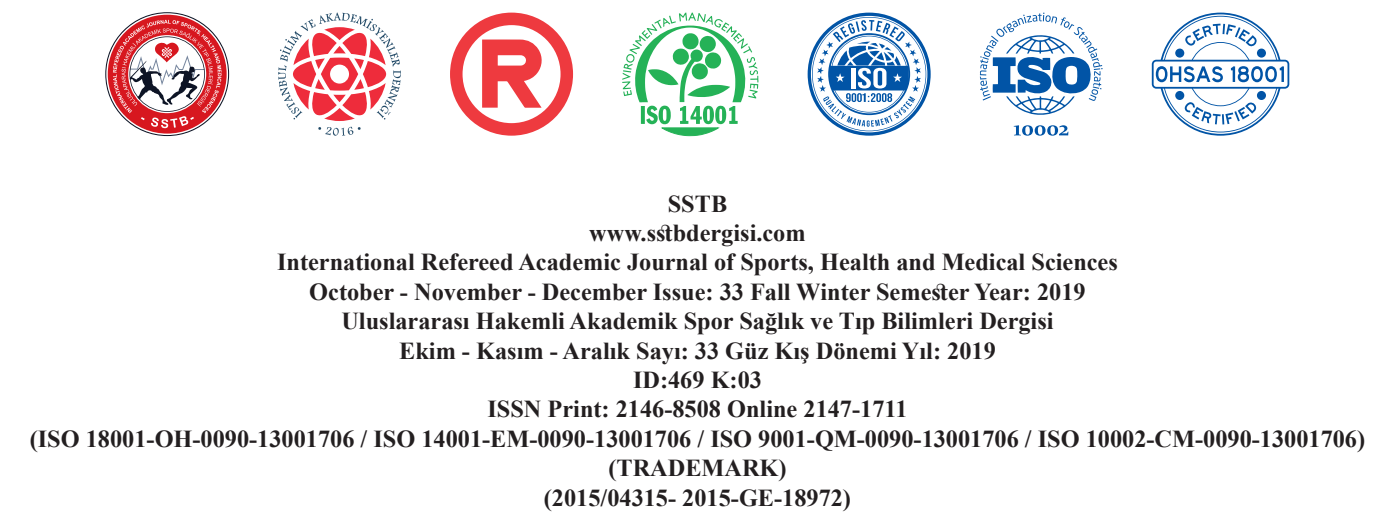

In all three models and methods, the examination of health services and health expenditures with all items, financial analysis, evaluation and comparisons contribute to revealing of risks and advantages (Sasam, 2017: 1-28). In recent years, health expenditures have been on the agenda of many countries. Health expenditures, which became more important due to the pressure created by the financial crisis on the public budget, have become the focus of saving measures. In such an environment and in this period when health system is transforming in Turkey, regular monitoring and analysis of health spending and policy is important in terms of sustainability debate (Memiş, Arslanhan, 2012).

Although health expenditures vary according to the development level of countries, it is observed that the vast majority of Turkey's total health expenditure has been realized by the public (Öztürk and Uçan, 2017: 139-147). The total health expenditures in a country are influenced by many factors such as the role of the public and private sector in the provision and financing of health services, the socioeconomic characteristics of the population, the relative price of health services and the capacity of the health system (Sülkü, 2011).

Health expenditures have an important place in the national economies. It is also one of the main indicators of development (Öztürk and Uçan, 2017: 139). Countries achieving a certain progress in terms of economic development have a higher share of expenditure on health (Mazgit, 2002: 405). Especially since 2003 when the implementation of the Health Transformation Program was applied, Turkey is above the OECD average regarding the increase in health spending. Improvements in access and the increase in population under the social security framework played an important role in the increase of expenditures (Yereli, Kobal and Köktaş, 2011).

Total health expenditures in Turkey in 2000 was realized as 8.248 million TL. Although this amount was low due to the global crisis experienced in 2008-2009, it increased steadily until 2016 (Giray and Çimen, 2018).

\section{HEALTH EXPENDITURES BY TYPE OF SERVICE AREA}

Healthcare services have a stable outlook since 2009 when consistent growth rates and client profile are examined.

The funding profile in the field of health expenditures has been stable since 2009, indicating a stable economic environment in terms of funding.

The share of the public sector in total expenditures was 78\% in 2017 and there has been no significant change since 2010 .

Compound annual growth rates (CAGR) are 9.8\% for General Government investments, 
SSTB

www.sstbdergisi.com

International Refereed Academic Journal of Sports, Health and Medical Sciences October - November - December Issue: 33 Fall Winter Semester Year: 2019

Uluslararası Hakemli Akademik Spor Sağlık ve Tıp Bilimleri Dergisi Ekim - Kasım - Aralık Sayı: 33 Güz Kıș Dönemi Yıl: 2019 ID:469 K:03

ISSN Print: 2146-8508 Online 2147-1711

(ISO 18001-OH-0090-13001706 / ISO 14001-EM-0090-13001706 / ISO 9001-QM-0090-13001706 / ISO 10002-CM-0090-13001706) (TRADEMARK)

(2015/04315- 2015-GE-18972)

$12 \%$ for Private Sector investments and Private sector investments are the main $10.2 \%$ for all investments between 2009 and growth factors.

2017.

Table 1. General Source of Financing

\begin{tabular}{|c|c|c|c|c|c|c|c|c|}
\hline \multicolumn{9}{|c|}{ Million TL } \\
\hline \multirow[b]{2}{*}{ Year } & \multirow[b]{2}{*}{$\begin{array}{c}\text { Total Gene- } \\
\text { ral Total }\end{array}$} & \multicolumn{4}{|c|}{ General Public } & \multicolumn{3}{|c|}{ Private Sector } \\
\hline & & $\begin{array}{c}\text { Total General } \\
\text { Public }\end{array}$ & $\begin{array}{c}\text { Total } \\
\text { Central } \\
\text { Public }\end{array}$ & $\begin{array}{l}\text { Total Lo- } \\
\text { cal Public }\end{array}$ & $\begin{array}{c}\text { Total Social } \\
\text { Security }\end{array}$ & $\begin{array}{c}\text { Total } \\
\text { Private } \\
\text { Sector }\end{array}$ & $\begin{array}{c}\text { Total Hou- } \\
\text { seholds }\end{array}$ & $\begin{array}{l}\text { Total } \\
\text { Other }\end{array}$ \\
\hline 2009 & 171.116も & 138.291 も & $52.551 も$ & 1.812 も & 83.928 も & 32.825 も & 24.306 も & 8.519 も \\
\hline 2010 & 181.978 も & 142.689 も & $49.725 も$ & 1.632 も & $91.332 も$ & 39.289 も & 30.015 も & 9.274 も \\
\hline 2011 & $202.586 も$ & 160.887 も & $55.402 も$ & 1.559 も & $103.926 も$ & 41.699 も & 31.570 も & $10.129 も$ \\
\hline 2012 & 218.665 も & 173.217 & $47.451 も$ & 1.856 も & $123.911 も$ & 45.448 も & 34.698 も & 10.749 も \\
\hline 2013 & $248.482 も$ & $194.903 も$ & $52.532 も$ & 2.258 も & $140.113 も$ & 53.579 も & 41.802 も & 11.777 も \\
\hline 2014 & 278.377 & $215.737 も$ & $60.776 も$ & 2.192 も & 152.769 も & 62.640 も & 49.392 も & 13.248 も \\
\hline 2015 & $305.921 も$ & $239.865 も$ & 70.837 も & $2.746 も$ & $166.281 も$ & $66.056 も$ & 51.034 も & $15.022 も$ \\
\hline 2016 & 352.052 も & $276.302 も$ & 81.752 も & 3.300 も & 191.250 も & 75.750 も & 57.655 も & 18.094 も \\
\hline 2017 & 412.276も & $321.273 も$ & 98.327 & 3.821 も & 219.125 も & 91.002 も & 70.778 も & 20.224 も \\
\hline
\end{tabular}

Table 2. Compound Annual Growth Rate (CAGR) - 2009 - 2017

\begin{tabular}{llll} 
& General Public & Private Sector & Total \\
\hline CAGR & $9,82 \%$ & $12,00 \%$ & $10,26 \%$
\end{tabular}

HEALTH EXPENDITURES TREND creased by 55.034 million TL each year. AcANALYSIS cordingly, total health expenditures of public and private service providers are expected to

Between 2009 and 2017, health expenditures of public and private service providers inbe 467.310 Million TL by the end of 2018 . 
SSTB

www.sstbdergisi.com

International Refereed Academic Journal of Sports, Health and Medical Sciences

October - November - December Issue: 33 Fall Winter Semester Year: 2019

Uluslararası Hakemli Akademik Spor Sağlık ve Tıp Bilimleri Dergisi

Ekim - Kasım - Aralık Sayı: 33 Güz Kıș Dönemi Yıl: 2019 ID:469 K:03

ISSN Print: 2146-8508 Online 2147-1711

(ISO 18001-OH-0090-13001706 / ISO 14001-EM-0090-13001706 / ISO 9001-QM-0090-13001706 / ISO 10002-CM-0090-13001706) (TRADEMARK)

(2015/04315- 2015-GE-18972)

Table 3. General Expenditures

\begin{tabular}{|c|c|c|c|}
\hline \multicolumn{4}{|c|}{ DependentVariable: HARCAMA } \\
\hline \multicolumn{4}{|l|}{ Method: LeastSquares } \\
\hline \multicolumn{4}{|l|}{ Sample: 20092017} \\
\hline \multicolumn{4}{|c|}{ Includedobservations: 9} \\
\hline Variable & Coefficient & Std. Error & Prob. \\
\hline @TREND & 55034.59 & 6069.076 & 0.0000 \\
\hline R-squared & -0.131563 & Meandependent var & 263494.8 \\
\hline Adjusted R-squared & -0.131563 & S.D. dependent var & 81488.87 \\
\hline S.E. of regression & 86683.74 & Akaikeinfocriterion & 25.68236 \\
\hline Sumsquaredresid & $6.01 \mathrm{E}+10$ & Schwarzcriterion & 25.70427 \\
\hline Loglikelihood & -114.5706 & Hannan-Quinncriter. & 25.63507 \\
\hline Durbin-Watson stat & 0.112852 & & \\
\hline
\end{tabular}

HEALTH EXPENDITURES BY TYPE OF SERVICE AREA

Since 2009, expenditures on private service providers have been growing head-to-head with the general service provider sector, indicating economic stability in the sector. In 2017, the share of private service providers in total health expenditures was $22 \%$.
The share of private sector service providers has increased significantly in the last five years due to the increase in private sector and household expenditures. In 2017, the share of private service providers in total private sector expenditures was $50 \%$ and the share of household expenditures was 39\%. 

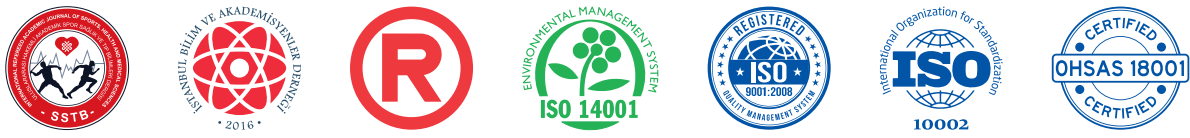

SSTB

www.sstbdergisi.com

International Refereed Academic Journal of Sports, Health and Medical Sciences October - November - December Issue: 33 Fall Winter Semester Year: 2019

Uluslararası Hakemli Akademik Spor Sağlık ve Tıp Bilimleri Dergisi Ekim - Kasım - Aralık Sayı: 33 Güz Kıș Dönemi Yıl: 2019 ID:469 K:03

ISSN Print: 2146-8508 Online 2147-1711

(ISO 18001-OH-0090-13001706 / ISO 14001-EM-0090-13001706 / ISO 9001-QM-0090-13001706 / ISO 10002-CM-0090-13001706) (TRADEMARK)

(2015/04315- 2015-GE-18972)

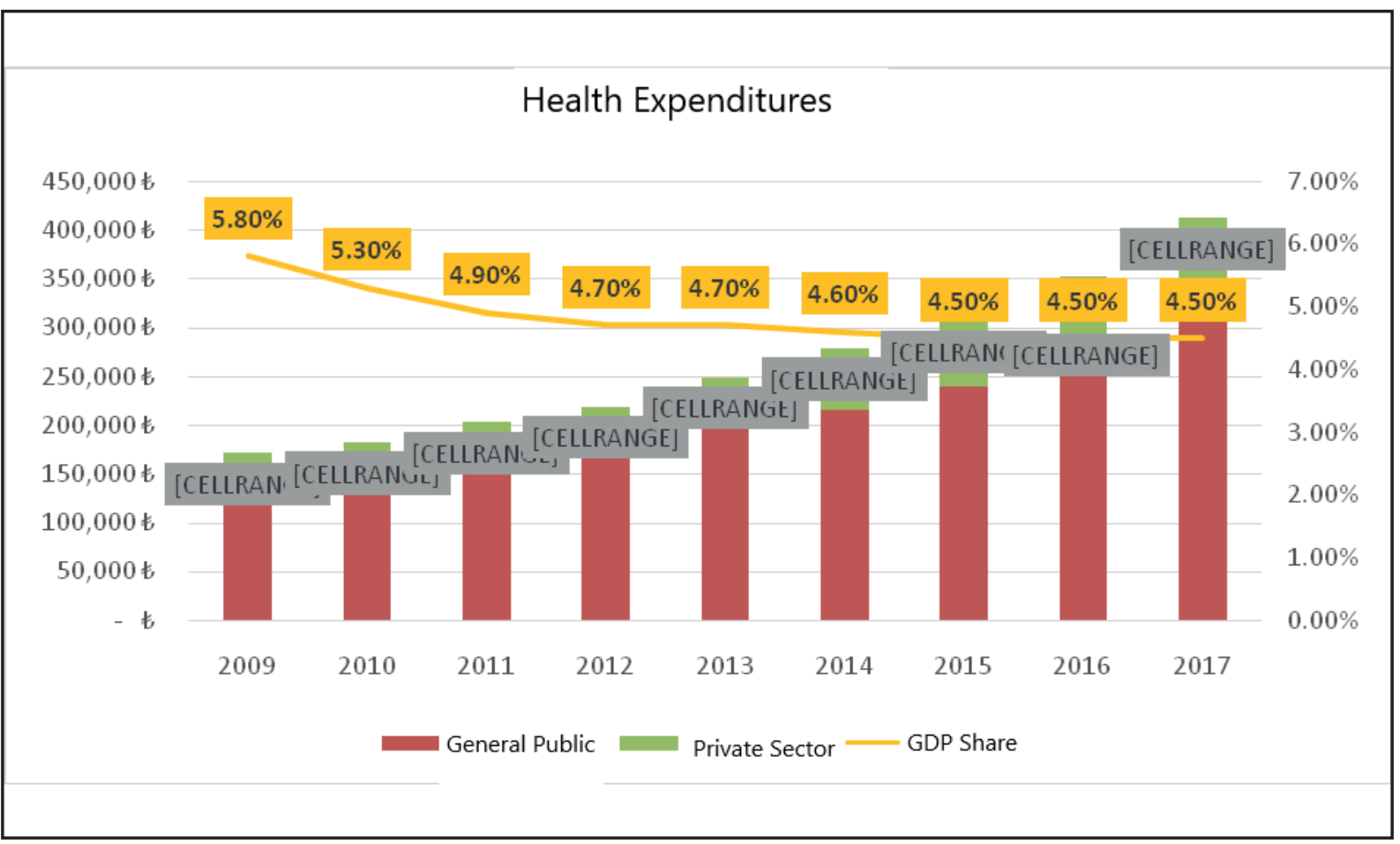

Figure 1. Health Expenditures by Years 

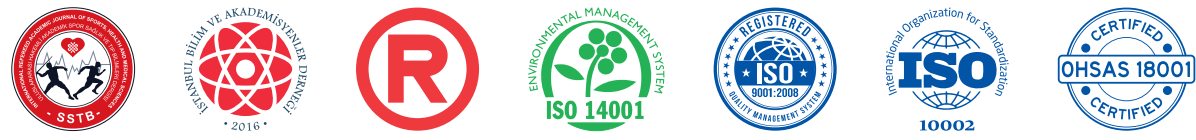

SSTB

www.sstbdergisi.com

International Refereed Academic Journal of Sports, Health and Medical Sciences

October - November - December Issue: 33 Fall Winter Semester Year: 2019

Uluslararası Hakemli Akademik Spor Sağlık ve Tıp Bilimleri Dergisi

Ekim - Kasım - Aralık Sayı: 33 Güz Kış Dönemi Yıl: 2019

ID:469 K:03

ISSN Print: 2146-8508 Online 2147-1711

(ISO 18001-OH-0090-13001706 / ISO 14001-EM-0090-13001706 / ISO 9001-QM-0090-13001706 / ISO 10002-CM-0090-13001706) (TRADEMARK)

(2015/04315- 2015-GE-18972)

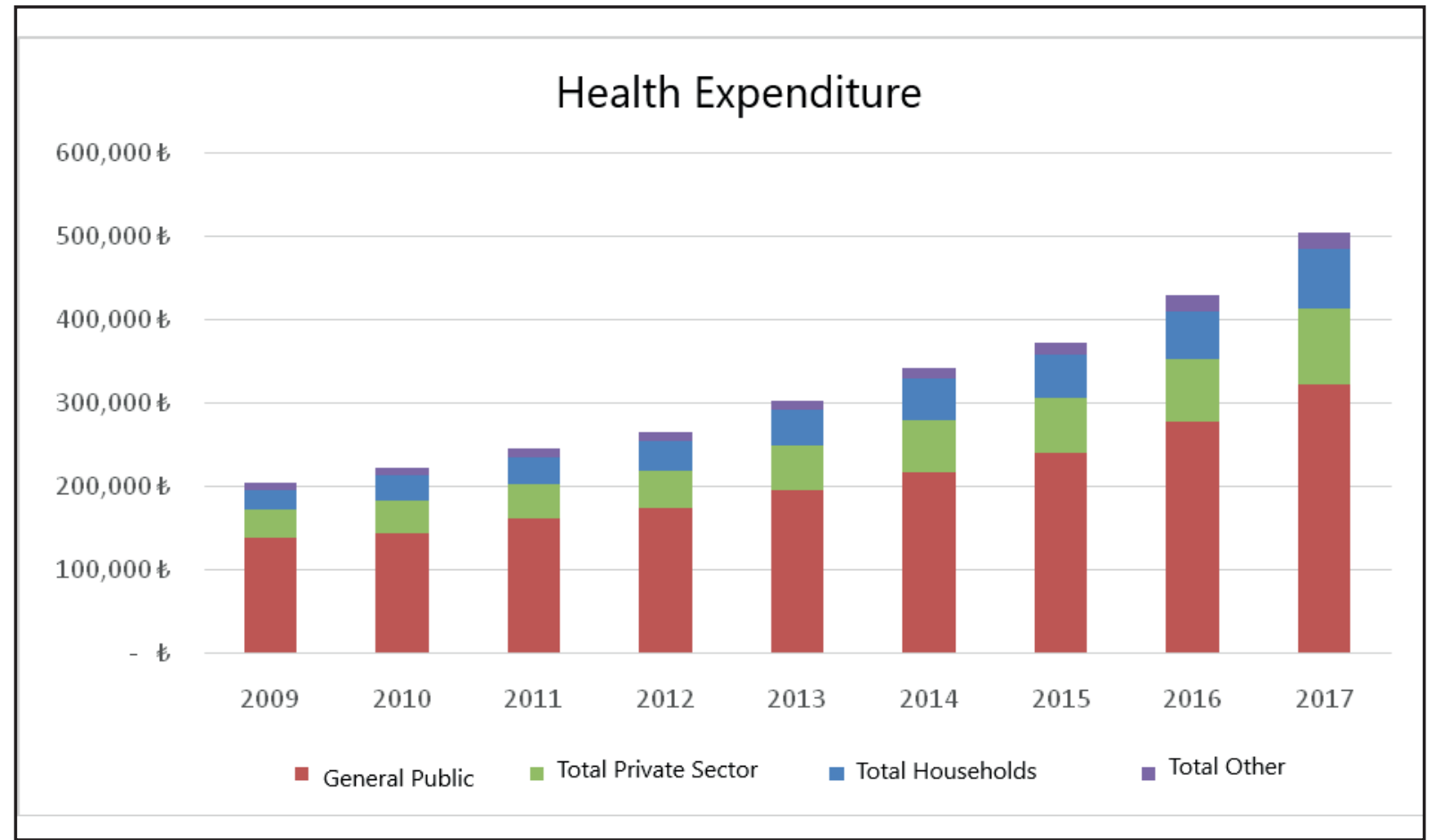

Figure 2. Health Expenditures by Years

PRIVATE HEALTH EXPENDITYRES TREND ANALYSIS

Between 2009 and 2017, health expenditures of private service providers increased by 11.096 million TL each year. According to this, total health expenditures of private service providers are expected to be 102.098 Million TL by the end of 2018. 
SSTB

www.sstbdergisi.com

International Refereed Academic Journal of Sports, Health and Medical Sciences October - November - December Issue: 33 Fall Winter Semester Year: 2019

Uluslararası Hakemli Akademik Spor Sağlık ve Tıp Bilimleri Dergisi Ekim - Kasım - Aralık Sayı: 33 Güz Kıș Dönemi Yıl: 2019 ID:469 K:03

ISSN Print: 2146-8508 Online 2147-1711

(ISO 18001-OH-0090-13001706 / ISO 14001-EM-0090-13001706 / ISO 9001-QM-0090-13001706 / ISO 10002-CM-0090-13001706) (TRADEMARK)

(2015/04315- 2015-GE-18972)

Table 4. General Expenditures

DependentVariable: HARCAMA

Method: LeastSquares

Sample: 20092017

Includedobservations: 9

\begin{tabular}{lllll}
\hline \hline Variable & $\begin{array}{l}\text { Coeffici- } \\
\text { ent }\end{array}$ & Std. Error & t-Statistic & Prob. \\
\hline \hline @TREND & 11966.42 & 1210.384 & 9.886463 & 0.0000 \\
\hline \hline R-squared & 0.174527 & Meandependent var & 56476.44 \\
\hline Adjusted R-squared & 0.174527 & S.D. dependent var & 19027.73 \\
\hline S.E. of regression & 17287.74 & Akaikeinfocriterion & 22.45782 \\
\hline Sumsquaredresid & $2.39 \mathrm{E}+09$ & Schwarzcriterion & 22.47974 \\
\hline Loglikelihood & -100.0602 & Hannan-Quinncriter. & 22.41053 \\
\hline Durbin-Watson stat & 0.126038 & & \\
\hline
\end{tabular}

INTERNATIONAL COMPARISON OF The share of health expenditures in GDP is THE SHARE OF CURRENT HEALTH lower than in other OECD countries. This inEXPENDITURES WITHIN GDP, (\%), dicates high growth potential. 

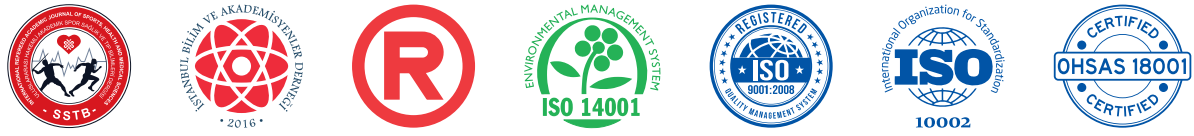

SSTB

www.sstbdergisi.com

International Refereed Academic Journal of Sports, Health and Medical Sciences

October - November - December Issue: 33 Fall Winter Semester Year: 2019

Uluslararası Hakemli Akademik Spor Sağlık ve Tıp Bilimleri Dergisi

Ekim - Kasım - Aralık Sayı: 33 Güz Kış Dönemi Yıl: 2019 ID:469 K:03

ISSN Print: 2146-8508 Online 2147-1711

(ISO 18001-OH-0090-13001706 / ISO 14001-EM-0090-13001706 / ISO 9001-QM-0090-13001706 / ISO 10002-CM-0090-13001706) (TRADEMARK)

(2015/04315- 2015-GE-18972)

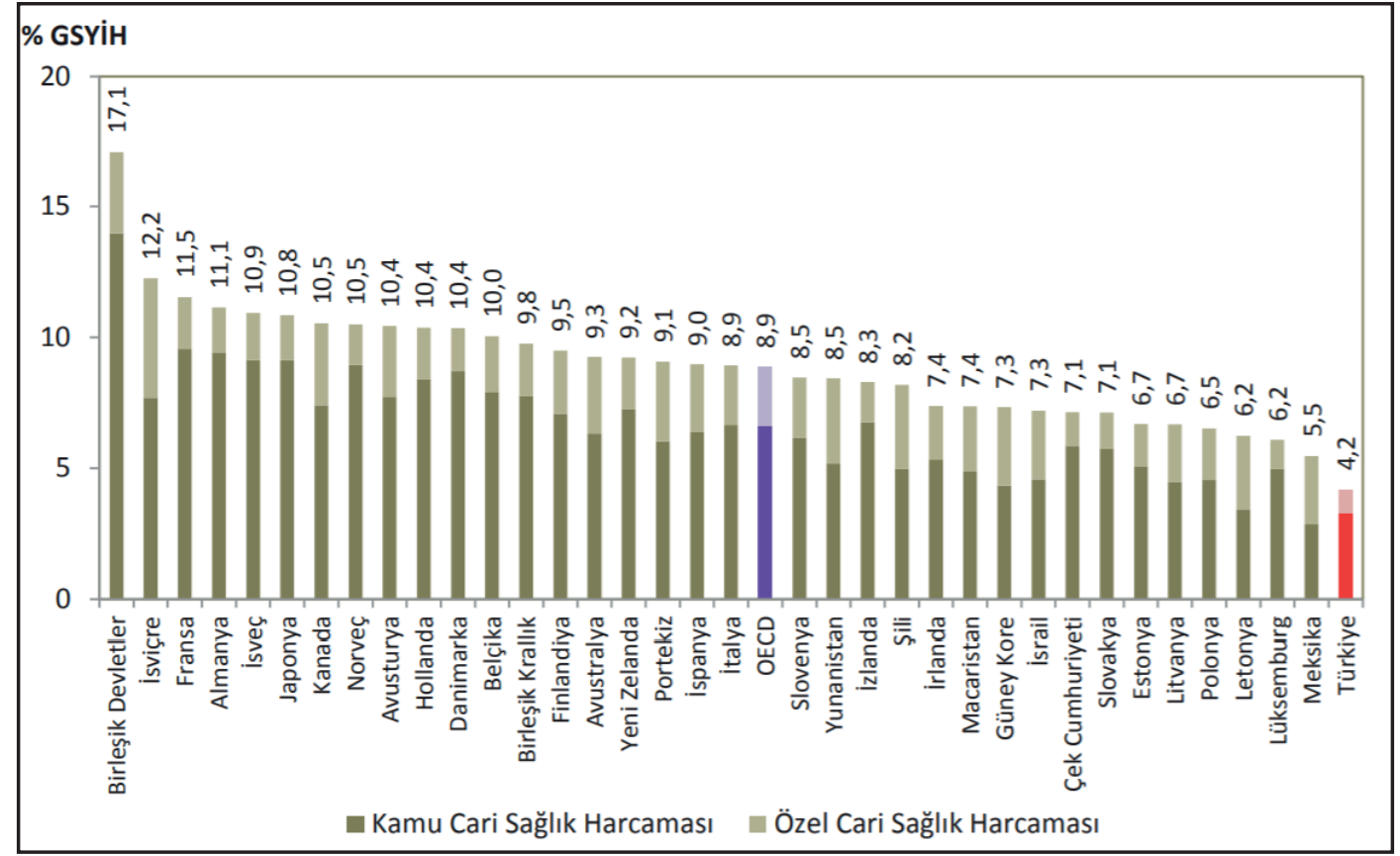

Figure 3. Public and Private Sector Current Health Expenditures

\section{DISTRIBUTION OF POPULATION BY AGE GROUPS}

The elderly and high-risk age groups in Turkey are growing faster than age segments in a way to indicate increase in health expenditures. The average annual growth rate of 35$39,40-44$ and $45+$ age groups was calculated to be $1.97 \%, 2.31 \%$ and $2.86 \%$ between 2009 and 2017, respectively. The share of the over 35 age group within the total population is increasing. Chronic discomfort is increasing in the aging population, indicating a potential increase in demand for health care.

The implementation of preventive measures to reduce risk factors and strengthen primary health care services, complex, integrated and long-term disability management demand and talent allocation, focus on medical education, and revision of health system components such as performance mechanisms are important for meeting the demand for health services. 
SSTB

www.sstbdergisi.com

International Refereed Academic Journal of Sports, Health and Medical Sciences October - November - December Issue: 33 Fall Winter Semester Year: 2019

Uluslararası Hakemli Akademik Spor Sağlık ve Tıp Bilimleri Dergisi

Ekim - Kasım - Aralık Sayı: 33 Güz Kıs Dönemi Yıl: 2019 ID:469 K:03

ISSN Print: 2146-8508 Online 2147-1711

(ISO 18001-OH-0090-13001706 / ISO 14001-EM-0090-13001706 / ISO 9001-QM-0090-13001706 / ISO 10002-CM-0090-13001706) (TRADEMARK)

(2015/04315- 2015-GE-18972)

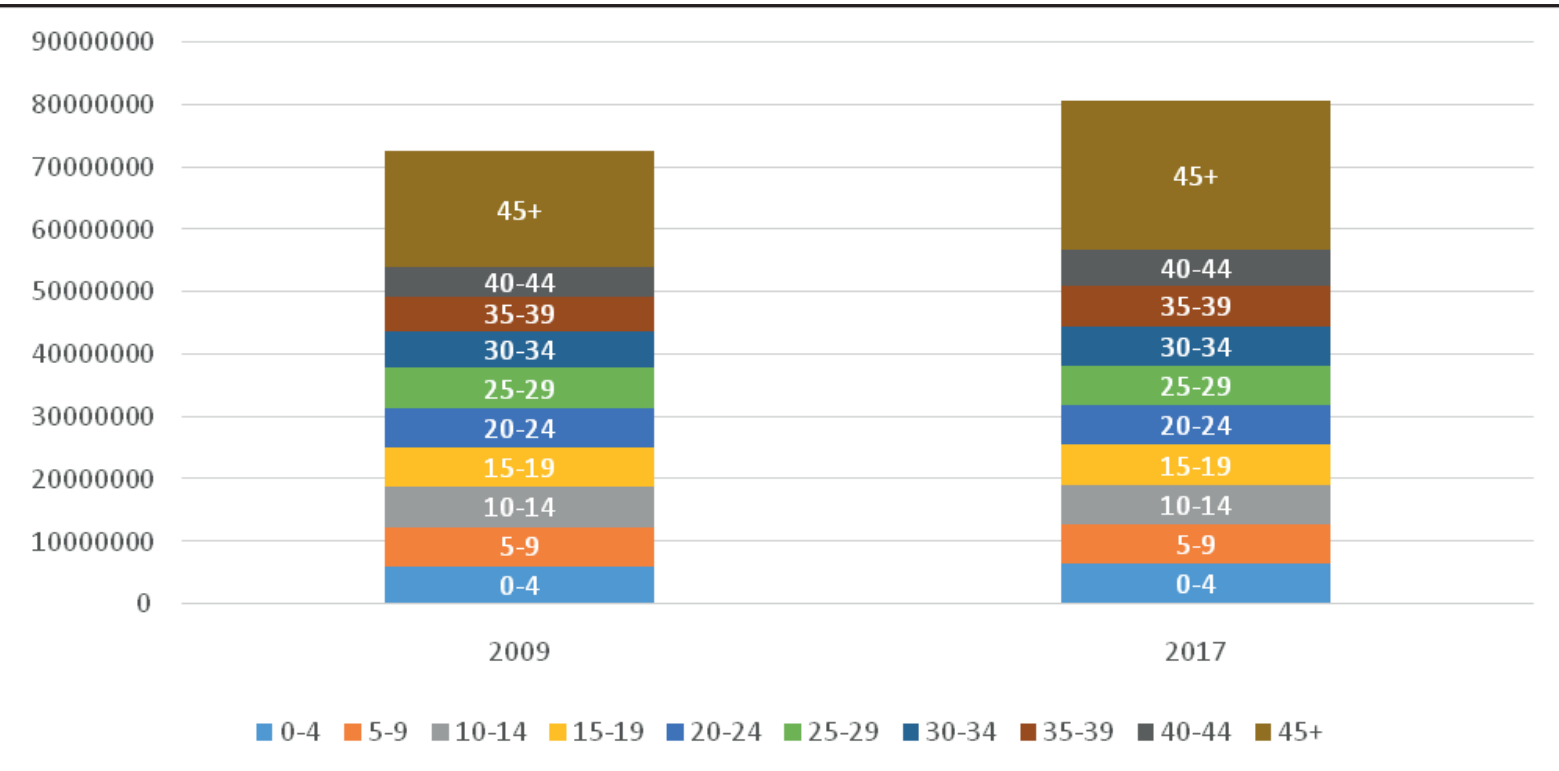

Figure 4. Indicators by Age Distribution

Table 5. Age Distribution and Percentage Rates (\%) in Health Expenditures

\begin{tabular}{lllllllllll} 
Age & $0-4$ & $5-9$ & $10-14$ & $15-19$ & $20-24$ & $25-29$ & $30-34$ & $35-39$ & $40-44$ & $45+$ \\
\hline CAGR & $0,58 \%$ & $0,25 \%$ & $-0,51 \%$ & $0,51 \%$ & $0,31 \%$ & $-0,48 \%$ & $0,71 \%$ & $1,97 \%$ & $2,31 \%$ & $2,86 \%$
\end{tabular}

DISTRIBUTION OF POPULATION BY groups could be noticed between years. As AGE GROUPS DIFFERENCES BE- a result of the analysis, the assumption that TWEEN YEARS there is no difference between age groups be-

The distribution of the population by age groups between 2009 and 2017 was examined. ANOVA analysis was performed to determine whether the ratio of age groups among all age ing the main hypothesis will be rejected since the probability value is less than 0.05 . When analyzed by years, the size of the age groups differ statistically. 
SSTB

www.sstbdergisi.com

International Refereed Academic Journal of Sports, Health and Medical Sciences

October - November - December Issue: 33 Fall Winter Semester Year: 2019

Uluslararası Hakemli Akademik Spor Sağlık ve Tıp Bilimleri Dergisi

Ekim - Kasım - Aralık Sayı: 33 Güz Kış Dönemi Yıl: 2019

ID:469 K:03

ISSN Print: 2146-8508 Online 2147-1711

(ISO 18001-OH-0090-13001706 / ISO 14001-EM-0090-13001706 / ISO 9001-QM-0090-13001706 / ISO 10002-CM-0090-13001706) (TRADEMARK)

(2015/04315- 2015-GE-18972)

Table 6. Anova Analysis

\begin{tabular}{llllll}
\hline & Sum of Squares & df & MeanSquare & F & Sig. \\
\hline BetweenGroups & $4,137 \mathrm{E} 14$ & 9 & $4,596 \mathrm{E} 13$ & 28,978 &, 000 \\
\hline WithinGroups & $1,586 \mathrm{E} 13$ & 10 & $1,586 \mathrm{E} 12$ & & \\
\hline Total & $4,295 \mathrm{E} 14$ & 19 & & &
\end{tabular}

\section{CONCLUSION}

Turkey's health expenditures have been growing steadily since 2009. Annual average growth rate is over $10 \%$. The sector size reached 412 billion TL in 2017.

By the end of 2018, total health expenditures of public and private service providers are expected to be 467.310 million TL.

Since 2009, expenditures on private service providers have been growing head-to-head with the general service provider sector, indicating economic stability in the sector. In 2017 , the share of private service providers in total health expenditures was $22 \%$.

By the end of 2018, total health expenditures of private service providers are expected to be 102,098 million TL.

The share of health expenditures in GDP is lower than other OECD countries. This indicates a high growth potential.

The elderly and high-risk age groups in Turkey are growing faster than age segments in a way to indicate increase in health expenditures
When analyzed by years, the size of the age groups differ statistically.

Looking at general terms, although we have incorporated limited information in our paper, we can say that public health expenditures for Turkey and developing countries of the world increase each passing day by population growth and other variables. The scientific studies and researches also confirm this situation. Therefore, we can state that public health expenditures and personal health expenditures occupy and constitute an important place for the national economy.

\section{REFERENCES}

AKINCI, A., GÜNER, T., (2016). “Türkiye'de Sağlık Harcamaları ile Ekonomik Büyüme Arasındaki İlişki”, Sayıştay Dergisi, Issue 102 (July-September), pp. 47- 61

ATUN, R., FIZPATRICK, S., (2005). Advancing economic growth: investing in health, A summary of the issues discussed at a Chatham House conference held on 22-23 June 
International Refereed Academic Journal of Sports, Health and Medical Sciences October - November - December Issue: 33 Fall Winter Semester Year: 2019

Uluslararası Hakemli Akademik Spor Sağlık ve Tıp Bilimleri Dergisi

Ekim - Kasım - Aralık Sayı: 33 Güz Kış Dönemi Yıl: 2019 ID:469 K:03

ISSN Print: 2146-8508 Online 2147-1711

(ISO 18001-OH-0090-13001706 / ISO 14001-EM-0090-13001706 / ISO 9001-QM-0090-13001706 / ISO 10002-CM-0090-13001706) (TRADEMARK)

ÇELIKK, Y., (2011). Türkiye Sağllk Harcamalarının Analizi ve Sağlı Harcama Düzeyinin Uygunluğunun Değerlendirilmesi, Sosyal Güvenlik Dergisi, Volume:1 Issue:1 pp.62-81

DEMIR, B., (2011). Sağlık Hizmetlerinin Özel Sektör Tarafindan Yürütülmesi, Ankara Üniversitesi, Sosyal Bilimler Enstitüsü, Master's Thesis, pp.1-115

GíRAY, F., ÇiMEN, G., (2018). Sağlık harcamalarının düzeyini belirleyen faktörler: Türkiye ve OECD ülkeleri analiz, Sayıştay Dergisi, Volume: 111, pp. 143171

MAZGIT, İ., (2002), "Bilgi Toplumu ve Sağlığın Artan Önemi”, I. Ulusal Bilgi, Ekonomi ve Yönetim Kongresi, pp. 405415

MEMIŞ, A.S., (2012). Son Dönemdeki Sağlık Harcamalarının Analizi, Türkiye Ekonomi Politikaları Araştırma Vakfı, TEPAV Yaşam Bilimleri ve Sağlık Politikası Enstitüsü, Accessed: https://www.tepav.org. tr/upload/files/1354282721-9.Son_Donemdeki_Saglik_Harcamalarinin_Analizi.pdf, Access Date: 19.11.2019

ÖZTÜRK, S., UÇAN, O., (2017). “Türkiye'de Sağlık Harcamalarında Artış Nedenleri: Sağlık Harcamalarında Artış - Büyüme İlişkisi”, Süleyman Demirel Üniversitesi
İktisadi ve İdari Bilimler Fakültesi Dergisi, Volume 22, Issue 1, pp. 139- 152

ÖZTÜRK, S., UÇAN, O., (2017). Türkiye'de Sağlık Harcamalarında Artış Nedenleri: Sağlık Harcamalarında Artış - Büyüme İlişkisi, Süleyman Demirel Üniversitesi İktisadi ve İdari Bilimler Fakültesi Dergisi, Volume 22, Issue 1, pp. 139- 152

SASAM, (2017). Türkiye Sağlık Harcamaları Analizi, Sağlık-Sen Sasam Yayınları, Year: 3 volume:10, pp.1-28

SÜLKÜ, S.N., (2011) “Türkiye'de Sağlıkta Dönüşüm Programı Öncesinde ve Sonrasında Sağlık Hizmetlerinin Sunumu, Finansmanı ve Sağlık Harcamaları", T.C. Maliye Bakanlığı Strateji Geliştirme Dairesi Başkanlığı Publication No. 2011/414, Ankara

ŞAHIN, D., TEMELLI, F., (2019). OECD Ülkelerinde Sağlık Harcamalarının Belirleyicileri: Panel Veri Analizi, Avrasya Uluslararası Araştırmalar Dergisi, 7 (16), 946-961

TIRAŞ, H.H., A ĞIR, H., (2017). D-8 Ülkelerinin Sağlık Harcamaları Bakımından Karşılaştırılması: Betimsel Bir Analiz, Kahramanmaraş Sütçü İmam Üniversitesi, İ̈BF Journal, Volume: 7, Issue: 2

TIRAŞ, H.H., A ĂIR, H., (2018). OECD Ülkelerinde Sağlık Harcamaları ve Eko- 
International Refereed Academic Journal of Sports, Health and Medical Sciences October - November - December Issue: 33 Fall Winter Semester Year: 2019

Uluslararası Hakemli Akademik Spor Sağlık ve Tıp Bilimleri Dergisi Ekim - Kasım - Aralık Sayı: 33 Güz Kış Dönemi Yıl: 2019 ID:469 K:03

ISSN Print: 2146-8508 Online 2147-1711

(ISO 18001-OH-0090-13001706 / ISO 14001-EM-0090-13001706 / ISO 9001-QM-0090-13001706 / ISO 10002-CM-0090-13001706) (TRADEMARK)

(2015/04315- 2015-GE-18972)

nomik Büyüme İlişkisi: Panel Nedensellik Analizleri, Research Journal of Politics, Economics and Management, October, (6) $4,13-29$

YAÇIN, A.Z., ÇAKMAK, F., (2016). Türkiye'de kamu sağlık harcamalarının insani gelişim üzerindeki etkisi, Atatürk Üniversitesi İktisadi ve İdari Bilimler Dergisi, 30 (4), 716
YERELI, A.B., KOBAL, I., KÖKTAŞ, A.M., (2011). Türkiye'de Sağl1k Harcamalarını Arttıran Faktörler, http://ahmetburcinyereli.com, Accessed: 19.11.2019

YURDADOĞ, V., (2007). Türkiye'de Sağlık Harcamalarının Finansmanı ve Analizi, Ç.Ü. Sosyal Bilimler Enstitüsü Dergisi, 16 (1), 591-610 